\title{
Redox Interactions of Vitamin C and Iron: Inhibition of the Pro-Oxidant Activity by Deferiprone
}

\author{
Viktor A. Timoshnikov ${ }^{1, *}$, Tatyana V. Kobzeva ${ }^{1}$, Nikolay E. Polyakov ${ }^{1}$ \\ and George J. Kontoghiorghes $2, *$ (i) \\ 1 Institute of Chemical Kinetics \& Combustion, 630090 Novosibirsk, Russia; kobzeva@mail.ru (T.V.K.); \\ polyakov@kinetics.nsc.ru (N.E.P.) \\ 2 Postgraduate Research Institute of Science, Technology, Environment and Medicine, \\ CY-3021 Limassol, Cyprus \\ * Correspondence: timoshnikov@kinetics.nsc.ru (V.A.T.); kontoghiorghes.g.j@pri.ac.cy (G.J.K.); \\ Tel./Fax: +7-383-3332947 (V.A.T.); +357-2627-2076 (G.J.K.)
}

Received: 21 February 2020; Accepted: 28 May 2020; Published: 31 May 2020

\begin{abstract}
Ascorbic acid $\left(\mathrm{AscH}_{2}\right)$ is one of the most important vitamins found in the human diet, with many biological functions including antioxidant, chelating, and coenzyme activities. Ascorbic acid is also widely used in medical practice especially for increasing iron absorption and as an adjuvant therapeutic in iron chelation therapy, but its mode of action and implications in iron metabolism and toxicity are not yet clear. In this study, we used UV-Vis spectrophotometry, NMR spectroscopy, and EPR spin trapping spectroscopy to investigate the antioxidant/pro-oxidant effects of ascorbic acid in reactions involving iron and the iron chelator deferiprone (L1). The experiments were carried out in a weak acidic ( $\mathrm{pH}$ from 3 to 5) and neutral ( $\mathrm{pH}$ 7.4) medium. Ascorbic acid exhibits predominantly pro-oxidant activity by reducing $\mathrm{Fe}^{3+}$ to $\mathrm{Fe}^{2+}$, followed by the formation of dehydroascorbic acid. As a result, ascorbic acid accelerates the redox cycle $\mathrm{Fe}^{3+} \leftrightarrow \mathrm{Fe}^{2+}$ in the Fenton reaction, which leads to a significant increase in the yield of toxic hydroxyl radicals. The analysis of the experimental data suggests that despite a much lower stability constant of the iron-ascorbate complex compared to the FeL1 $1_{3}$ complex, ascorbic acid at high concentrations is able to substitute $\mathrm{L} 1$ in the FeL1 3 chelate complex resulting in the formation of mixed $\mathrm{L}_{2} \mathrm{AscFe}$ complex. This mixed chelate complex is redox stable at neutral $\mathrm{pH}=7.4$, but decomposes at $\mathrm{pH}=4-5$ during several minutes at sub-millimolar concentrations of ascorbic acid. The proposed mechanisms play a significant role in understanding the mechanism of action, pharmacological, therapeutic, and toxic effects of the interaction of ascorbic acid, iron, and L1.
\end{abstract}

Keywords: vitamin C; ascorbic acid; iron toxicity; iron chelation; deferiprone; Fenton reaction; hydroxyl radical; ascorbyl radical; EPR spin trapping; TMIO spin trap

\section{Introduction}

Vitamin $\mathrm{C}$ or ascorbic acid $\left(\mathrm{AscH}_{2}\right.$, Scheme 1$)$ is a powerful water-soluble antioxidant, found in nature and present in fresh fruit and vegetables [1-3]. Ascorbic acid is also known as a reducing agent and a radical scavenger. As a radical scavenger $\mathrm{AscH}_{2}$ provides effective protection of membranes and proteins against oxidation by reactive oxygen species (ROS): superoxide $\left(\mathrm{O}_{2}{ }^{\bullet-}\right)$, hydrogen peroxide $\left(\mathrm{H}_{2} \mathrm{O}_{2}\right)$, hydroxyl radicals $(\bullet \mathrm{OH})$, peroxyl radicals $(\bullet \mathrm{OOH})$, and singlet oxygen ${ }^{1} \mathrm{O}_{2}$, especially at high concentrations [4,5]. 
<smiles>O=C1OC(C(O)CO)C(O)=C1O</smiles>

$\mathrm{AscH}_{2}$

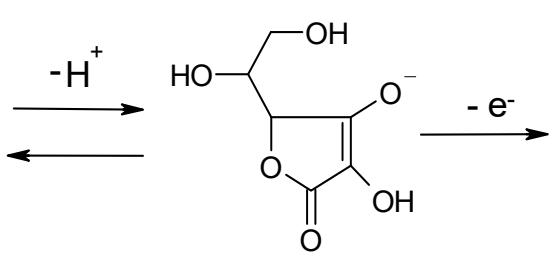

$\mathrm{AscH}^{-}$<smiles>CC1[Te]C[C+]1OC1=C(O)C(=O)OC1C(O)CO</smiles>

$\mathrm{AscH}$<smiles>O=C1OC(C(O)CO)C(=O)C1=O</smiles>

DHA

Scheme 1. The structure of ascorbic acid and the main products of redox reactions. Ascorbic acid- $\mathrm{AscH}_{2 .}$; ascorbate anion- $\mathrm{AscH}^{-}$; ascorbyl radical— $\mathrm{AscH}^{\bullet}$; dehydroascorbic acid—DHA.

However, ascorbic acid is a multifaceted compound that can act as a chelator and also as a source of free radicals [6-10]. The role of ascorbic acid as a chelator in iron and copper overload conditions is widely discussed [11-13]. In this regard, the literature intensively discusses the possibility of using ascorbic acid to treat advanced cancer in combination with anticancer agents [14-25]. In particular, some researchers have demonstrated biological validity and are ready to study the potential value of ascorbic acid in the treatment of cancer in humans [17]. However, the evidence that ascorbic acid could help human cancer patients is still thin and requires additional study. The results of published studies fail to prove that there is a clinically relevant positive effect of ascorbic acid supplementation in cancer patients in general on the overall survival, clinical status, quality of life and performance status $[1,14,26]$.

Iron is an essential element of life. It plays an important role in many cellular processes including energy production, oxygen transport, DNA synthesis, as well as in many other important metabolic processes involving iron-containing enzymes $[6,10]$. The catalytic activity of iron stems from its redox properties, namely the ability to alternate between two oxidation states, $\mathrm{Fe}^{3+}$ and $\mathrm{Fe}^{2+}$, acting as an electron donor or acceptor. On the other hand, an excess of iron is toxic because it can cause the formation of an excessive amount of ROS, which can subsequently cause biomolecular, subcellular, cellular, and tissue damage. Excess toxic iron has been identified in many diseases, such as age-related macular degeneration, age-related Alzheimer's and Parkinson's diseases, as well as cancer [6,26-32].

Iron chelation therapy is widely used to prevent poisoning by removing excess iron caused from repeated blood transfusions and other iron overload diseases. It includes the use of various chelating agents that bind and remove excess iron from the body. [6,26,32-34]. In this regard, numerous studies have been conducted to elucidate the redox activity of iron in chelate complexes [35-39]. As an example, we recently demonstrated the inhibition of iron- and copper-induced hydroxyl radical production by the water-soluble chelator deferiprone (L1, Figure 1) [39,40]. L1 is an effective iron-chelating drug developed for the treatment of iron overload toxicity in thalassaemia and other iron-related toxicity conditions. L1 is orally active and widespread in the body, thus binding toxic iron in many tissues and organs, including the brain [41-43]. Moreover, L1 is supposed to be an effective antioxidant that prevents oxidative stress and biomolecular, subcellular, cellular, and tissue damage caused mainly by iron and copper-induced free radical formation [43]. The physicochemical and coordination properties of the L1 complex with iron have been previously studied in detail by many investigators $[41,42,44-46]$.

In contrast, ascorbic acid is generally regarded as a weak chelating agent and cannot compete in iron binding with L1 and other stronger chelators. The coordination chemistry of ascorbic acid has been extensively studied in response to problems associated with its hydrolysis and redox reactions, as well as with the instability of its complexes [47-53]. As a weak dibasic acid (pKa1 = 4.25 and $\mathrm{pKa} 2=11.79)$, at physiological $\mathrm{pH}$ ascorbic acid exists as monoanion $\left(\mathrm{AscH}^{-}\right)$with deprotonation of $\mathrm{O}(3)-\mathrm{H}$ (see Scheme 1). The monoanionic form is quite stable due to the delocalisation of the negative charge between the oxygen atoms $\mathrm{O}(1)$ and $\mathrm{O}(3)$. Although ascorbic acid has several donor atoms capable of forming an iron complex (see Scheme 1), the interaction of ascorbic acid with ions of iron or other metals is mainly thought to occur by chelation through $\mathrm{O}(3)$ and $\mathrm{O}(2)$ nuclei accompanied by hydrogen displacement [53]. 


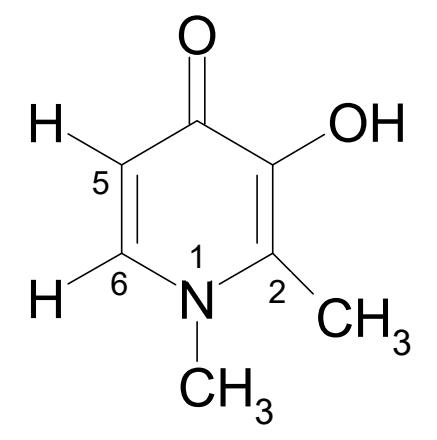

Figure 1. The chemical structure of deferiprone (L1).

Some researchers have used time-resolved stop-flow spectrophotometry to follow the reactions of ascorbic acid with $\mathrm{Fe}^{3+}$ in aqueous solutions and found evidence of blue intermediates in the reduction pathway of iron at low $\mathrm{pH}$ [47]. It has been shown that the reaction proceeds on a millisecond time scale with the subsequent formation of the oxidation product of ascorbic acid, namely dehydroascorbic acid (DHA) (see Scheme 1). These and other researchers pointed to the rapid reduction of $\mathrm{Fe}^{3+}$ via intramolecular electron transfer with simultaneous production of the ascorbyl radical $\left(\mathrm{AscH}^{\bullet}\right)$ [38-40,47].

It is assumed that some of the above mechanisms occur in plants, where iron is delivered to embryos in the form of ferric complexes with citrate and malate [48]. In this context, embryos efflux a large amount of ascorbic acid which chemically reduces and releases $\mathrm{Fe}^{3+}$ from citrate and malate complexes. It was concluded that ascorbic acid plays a key role in the chemical reduction and transport of $\mathrm{Fe}^{2+}$. The interaction of ascorbic acid with iron complexes of (1,3)-bis-(2-hydroxybenzamido)propane and $\mathrm{N}, \mathrm{N}^{\prime}$-ethylene-bis-salicylamide has also been studied $[45,46]$. It was shown that these complexes undergo a quick reaction with ascorbic acid to form ternary complexes in which $\mathrm{AscH}^{-}$is chelated with the $\mathrm{Fe}^{3+}$ centre. Furthermore, it was also reported that these ternary complexes undergo intramolecular electron transfer with the formation of $\mathrm{Fe}^{2+}$ and dehydroascorbic acid [51]. Other investigators have applied density functional theory calculations to elucidate the structures and relative stability of $\mathrm{Fe}^{3+}$ complexes with various ligands (aminoguanidine, pyridoxamine, EDTA, and ascorbic acid). The distorted neutral octahedral complex containing one iron atom and three molecules of ascorbic acid was found to be the most stable, but it was still energetically less stable by $92.7 \mathrm{kcal} / \mathrm{mol}$ than the EDTA complex. However, it is worth noting that in an in vivo study the acute pro-oxidant effects of ascorbic acid in EDTA chelation therapy were demonstrated when patients were administered a standard EDTA cocktail solution with $5 \mathrm{~g}$ of sodium ascorbate [52].

Ascorbic acid is sold as a dietary supplement and is used daily by millions of people worldwide. It is also widely used in medical practice especially for increasing iron absorption and as an adjuvant in iron chelation therapy. Nevertheless, the mode of action of ascorbic acid and its interactions with iron, other metals, and natural or synthetic chelators including chelating drugs is not yet fully clarified [5].

In the present study, we applied a set of physicochemical methods (UV-Vis spectrophotometry, nuclear magnetic resonance (NMR) and electron paramagnetic resonance (EPR) spin trapping techniques) to answer major questions which may have wide implications in the dietary and clinical use of ascorbic acid in conjunction with iron. One of these questions is whether ascorbic acid works as a pro-oxidant in the biologically important Fenton reaction. Another question is whether ascorbic acid is able to compete in iron-binding and antioxidant activity with the iron-chelating drug L1 at low and high concentrations. 


\section{Results}

\subsection{UV-Vis Optical Study of the Interaction of Ascorbic Acid with the Iron-Deferiprone Chelate Complex}

As was previously demonstrated in [39], the $\mathrm{FeL}_{3}$ chelate complex has a broad absorption band of around $500 \mathrm{~nm}$ in water solution (Figure 2a). After the addition of ascorbic acid, the position of this band was shifted to a lower wavelength (Figure $2 b, c$ ). We assume that this change is due to a change in the structure of the chelate complex. To measure the characteristic time of this reorganisation we measured the time profile of changes in optical density of solution at $525 \mathrm{~nm}$ after the addition of ascorbic acid. The rate of this process at neutral $\mathrm{pH}=7.4$ depends on the concentration of ascorbic acid with characteristic times of 350 second $(\mathrm{s})$ at $\left[\mathrm{AscH}^{-}\right]=0.05 \mathrm{mM}$, and $25 \mathrm{~s}$ at $\left[\mathrm{AscH}^{-}\right]=0.5 \mathrm{mM}$ (Figure $2 \mathrm{~b}$ ). However, in a weak acid solution at $\mathrm{pH}=4-5$ this new complex was unstable, and decayed completely with a characteristic time of several minutes (Figure 2c).
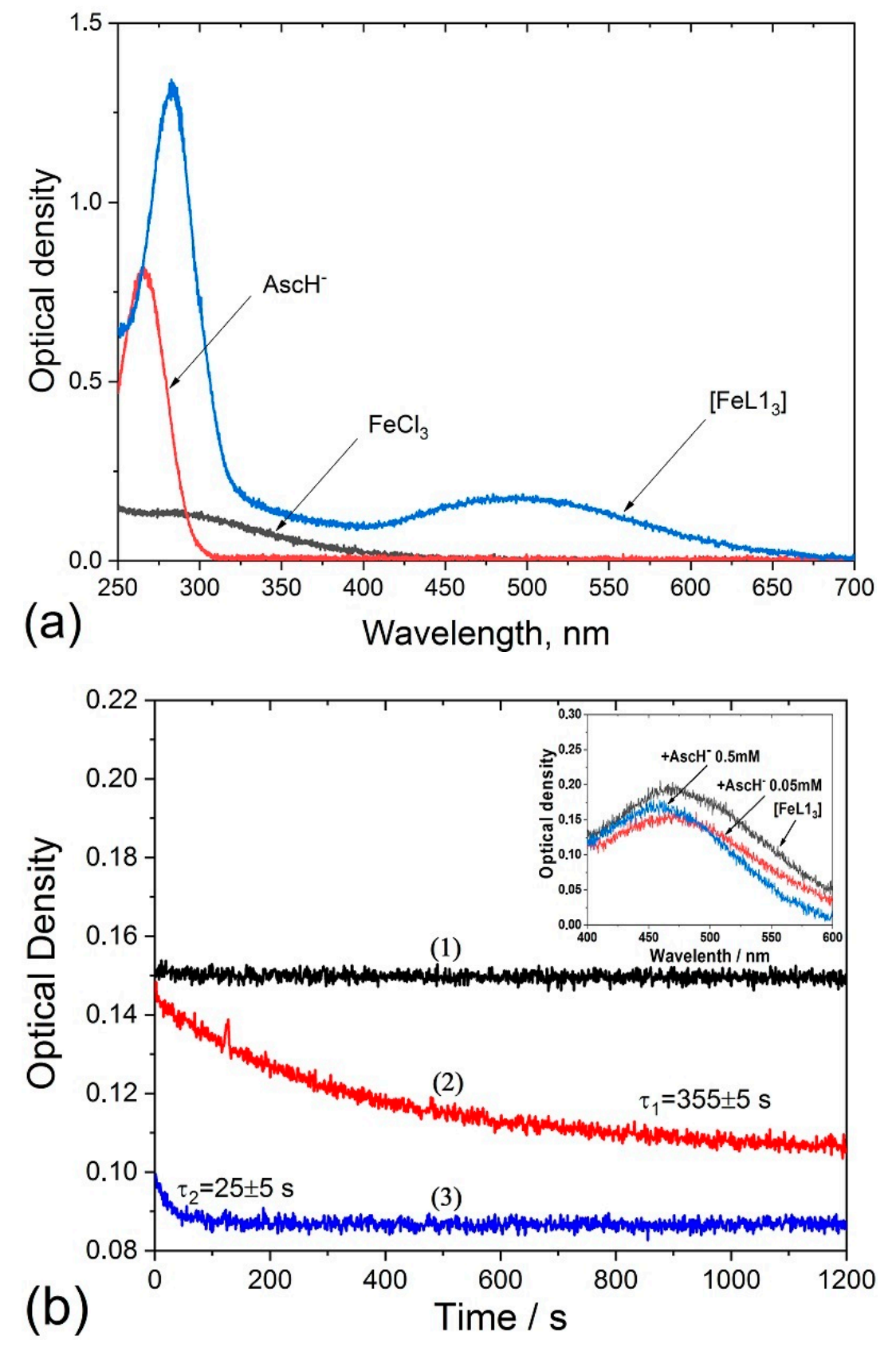

Figure 2. Cont. 


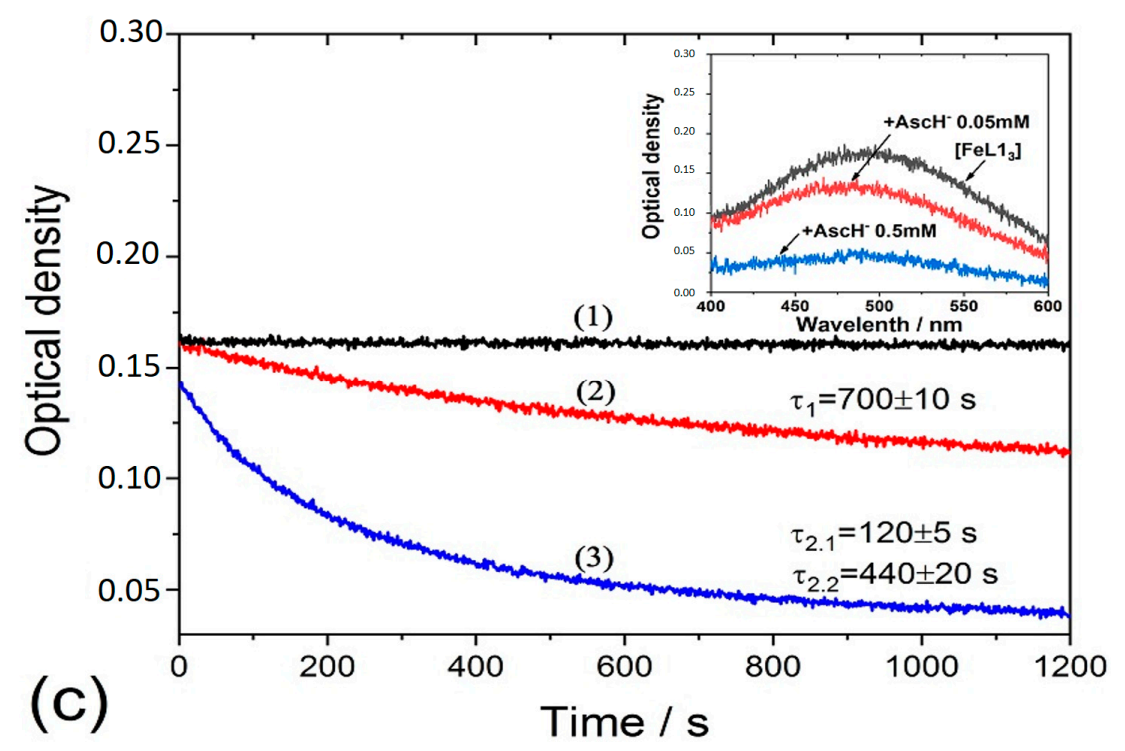

Figure 2. (a) Absorption spectra of ascorbic acid (0.05 mM), $\mathrm{FeCl}_{3}(0.05 \mathrm{mM})$, and $\left[\mathrm{FeL}_{3}\right]$ chelate complex $(0.05 \mathrm{mM})$ in a water solution at $\mathrm{pH}=4.8$; $(\mathbf{b})$ time profile of the changes of optical density at $525 \mathrm{~nm}$ of $\mathrm{FeL}_{3}$ chelate complex aqueous solution at $\mathrm{pH}=7.4$ in the absence (1) and presence of ascorbic acid at $0.05 \mathrm{mM}(2)$ and $0.5 \mathrm{mM}(3)$ at room temperature $\left(25^{\circ} \mathrm{C}\right)$; (c) similar time profiles measured at $\mathrm{pH}=4.2$.

\subsection{NMR Study of the Interaction of Ascorbic Acid with Iron-Deferiprone Chelate Complex}

To find out whether the decay of the mixed chelate complex in acidic media results in oxidation of ascorbic acid, we applied the NMR technique. The formation of DHA in the reaction of ascorbic acid with the $\mathrm{FeL}_{3}$ chelate complex in a weak acidic solution was confirmed by ${ }^{1} \mathrm{H}$ NMR spectroscopy. Figure 3 shows the appearance of the DHA signal after the addition of FeL1 3 complex to the ascorbic acid solution, with further increases in the amount of product during the next hour. We can assume that further decomposition of ascorbic acid occurs due to the release of ferrous ions from the L1 complex $[39,54]$ and its oxidation by dissolved oxygen [10]. The concentration of ascorbic acid in this experiment was $0.4 \mathrm{mM}$, and the concentration of $\mathrm{FeL}_{1}$ was $0.1 \mathrm{mM}$.

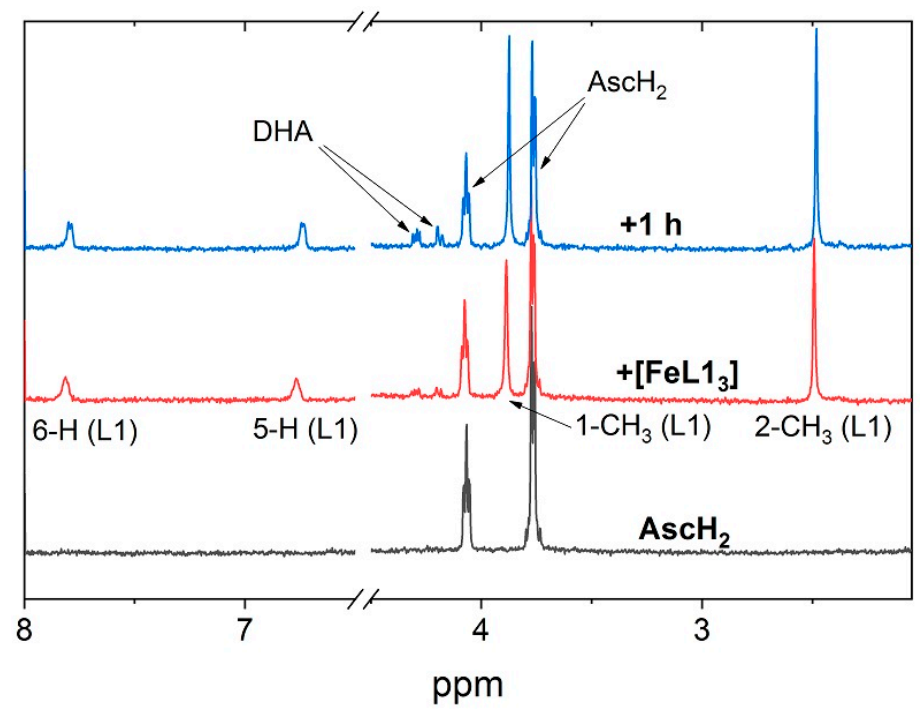

Figure 3. Fragments of the ${ }^{1} \mathrm{H}$ NMR spectra of $0.4 \mathrm{mM}$ of ascorbic acid in $\mathrm{D}_{2} \mathrm{O}$ at $\mathrm{pH}=4.1$ in the absence and in the presence of $0.1 \mathrm{mM}$ of $\mathrm{FeL}_{3}$ complex just after mixing and after one-hour storage at room temperature. 
2.3. EPR Spin Trapping Study of the Hydroxyl Radicals Production in the Fenton Reaction and the Effects of Ascorbic Acid and Deferiprone

The antioxidant/pro-oxidant activities of ascorbic acid were investigated in Fenton type reactions in the absence and presence of L1 using the EPR spin trapping technique. The TMIO spin trap was used for the detection of hydroxyl radicals in these experiments (Scheme 2).<smiles>CC1=CC(C)(C)N([O])C1</smiles>

Scheme 2. The structures of the TMIO spin trap and spin adduct with $\mathrm{OH}$ radical.

The TMIO spin trap provides more distinguishable individual spectra with the $\bullet \mathrm{OH}$ radical than the widely used DMPO spin trap [55-57]. In addition, 2H-imidazole 1-oxides do not form superoxide spin adducts in the xanthine/xanthine oxidase system. This is why the use of this spin trap makes the analysis much easier especially where several types of ROS are formed, for example in the Fenton type reaction induced by $\mathrm{Cu}$ or Fe ions [58-63].

The formation of $\bullet \mathrm{OH}$ radicals in the systems under study was proved by the detection of the corresponding TMIO-OH spin adduct with HFC constants: $a(N)=14.07 \mathrm{G}, \mathrm{a}(\mathrm{H})=16.08 \mathrm{G}$ (Figure 4) $[39,40,55,64]$. It was found that the signal from $\bullet \mathrm{OH}$ spin adducts increased after addition of ascorbic acid to the solution in the absence of L1, as well as in the presence of low concentrations of L1 (L1:Fe $=0$ or 1:1, see Figure $4 \mathrm{a}, \mathrm{b}$ ).
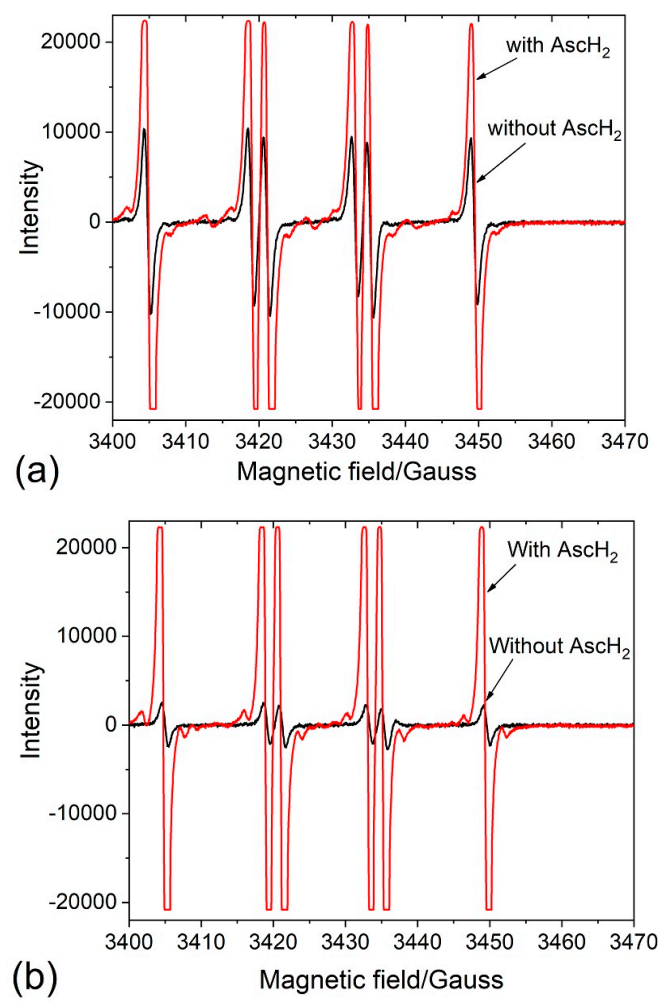

Figure 4. EPR spectra of TMIO-OH spin adduct in the absence (black) and presence (red) of ascorbic acid (a) without L1 and (b) in the presence of $3 \mathrm{mM} \mathrm{L1}$. Experiments were performed at room temperature in distilled water at $\mathrm{pH}=3.3$; reaction mixture: $20 \mathrm{mM} \mathrm{TMIO} ; 3 \mathrm{mM} \mathrm{FeCl}_{3} ; 12 \mathrm{mM} \mathrm{H}_{2} \mathrm{O}_{2}$; $10 \mathrm{mM}$ ascorbic acid. 
However, the situation changed with an increase in the concentration of ascorbic acid from 10 to $100 \mathrm{mM}$ in the reaction mixture. The observed amount of TMIO-OH spin adduct decreased in the presence of ascorbic acid in solution when the concentration ratios of $\mathrm{L} 1: \mathrm{Fe}=2: 1$ or 4:1 were used (Figures 5 and 6). Although the optical study shows slow decay of the FeL1 3 complex in the presence of ascorbic acid in a weak acidic solution (see Figure 2c), we can assume the competition in the trapping of the hydroxyl radical by spin trap and ascorbic acid. An additional factor that can affect the intensity of the spin adduct signal is the transformation of the spin adduct to the corresponding hydroxylamine in acidic media. Due to its diamagnetic nature, hydroxylamine is an EPR silent compound. This process becomes important when the rate of hydroxyl radical production decreases due to chelate complexes FeL1 ${ }_{2}$ Asc or FeL1 $1_{3}$ formation.

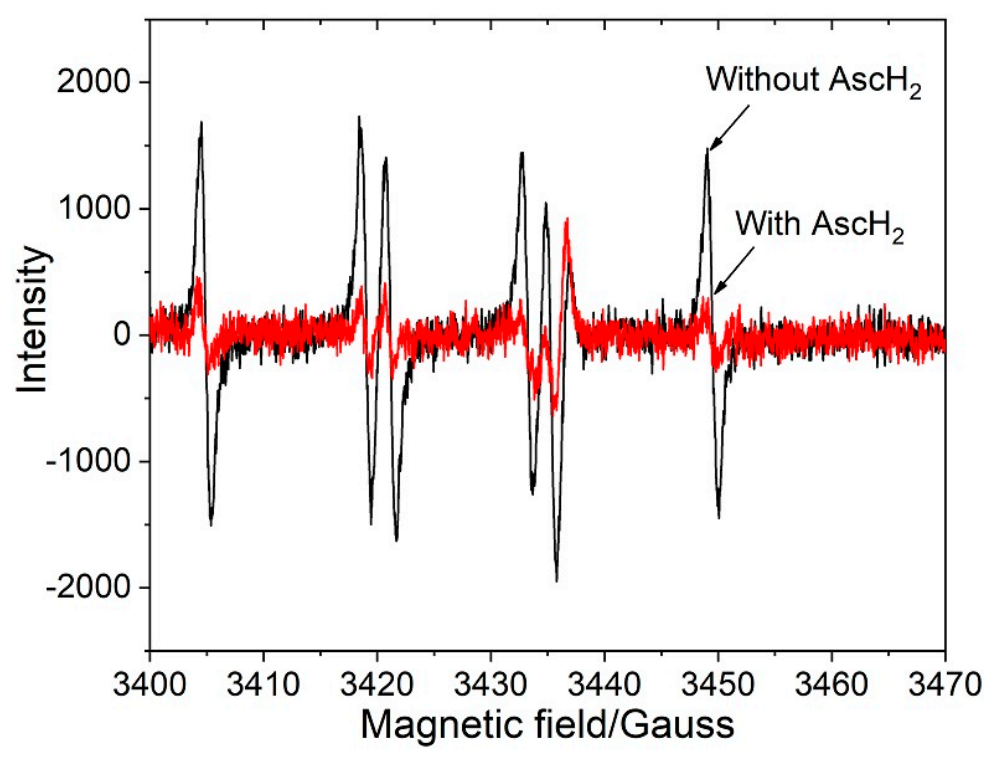

Figure 5. EPR spectra of TMIO-OH spin adduct in the absence (black) and presence (red) of $100 \mathrm{mM}$ ascorbic acid in the presence of $6 \mathrm{mM} \mathrm{L1}$. Reaction mixture: $20 \mathrm{mM}$ TMIO; $3 \mathrm{mM} \mathrm{FeCl}_{3} ; 12 \mathrm{mM} \mathrm{H}_{2} \mathrm{O}_{2}$; $\mathrm{pH}=3.0$.

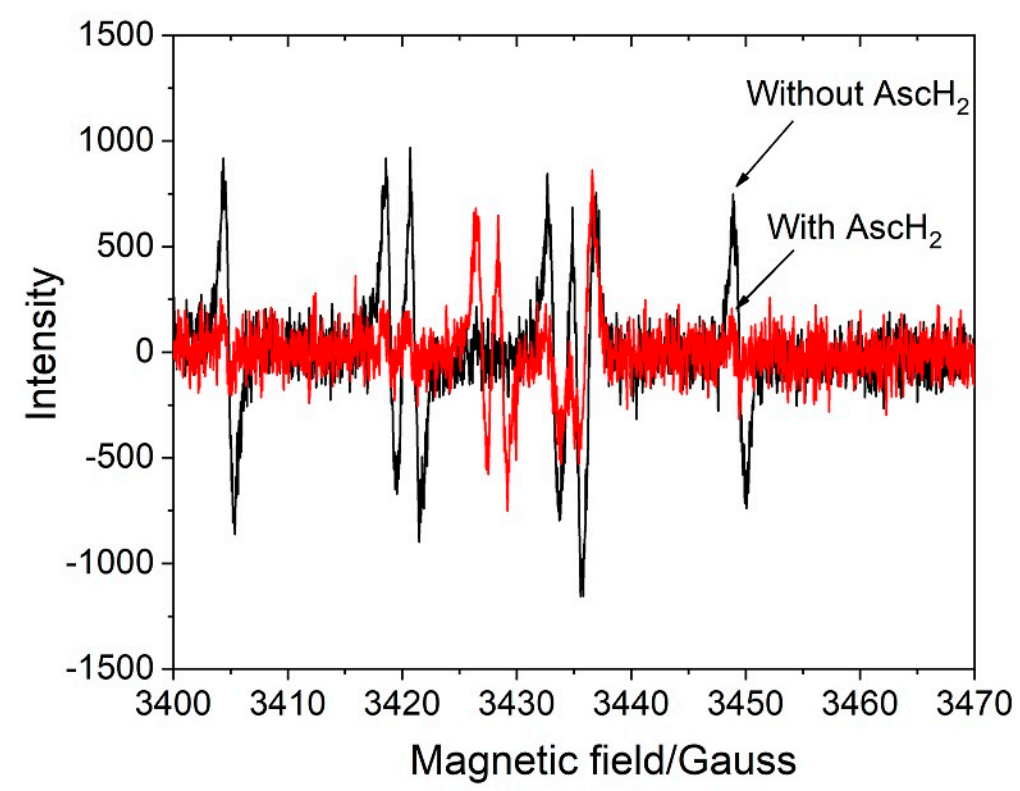

Figure 6. EPR spectra of TMIO-OH spin adduct in the absence (black) and presence (red) of $100 \mathrm{mM}$ ascorbic acid in the presence of $12 \mathrm{mM} \mathrm{L1} ; 20 \mathrm{mM} \mathrm{TMIO} ; 3 \mathrm{mM} \mathrm{FeCl}_{3} ; 12 \mathrm{mM} \mathrm{H}_{2} \mathrm{O}_{2} ; \mathrm{pH}=3.0$. 
With an increase of the L1:Fe ratio from 2:1 to 4:1, we observed a further decrease in the signal intensity from the TMIO-OH spin adduct in accordance with our previous studies on the antioxidant activity of L1 $[39,40]$. Surprisingly, in these conditions, we detected the signal from ascorbyl radicals with EPR parameters: $a(H)=1.8$ G (Figure 6) [65].

\section{Discussion}

The experimental findings of this study have several important biological and physiological implications for understanding the interaction of ascorbic acid with iron and L1. Under certain conditions ascorbic acid causes the reduction of ferric to ferrous iron, resulting in an increase of ROS production, in particular hydroxyl radical production, leading to oxidation to ascorbyl radicals and dehydroascorbic acid. Additionally, ascorbic acid is able to form mixed iron complexes with L1 and possibly with other chelators which may be redox-active or redox-inactive. The significance of these processes is underlined below from the different experiments carried out within this study.

It is known, that ascorbic acid is oxidised by $\mathrm{Fe}^{3+}$ ions through an intermediate chelate complex, forming a stable ascorbyl radical and the redox-active $\mathrm{Fe}^{2+}$ ion, which initiates a cascade of redox reactions with the formation of ROS (Scheme 3):

$$
\begin{aligned}
& \mathrm{Fe}^{3+}+\mathrm{AscH}^{-} \longrightarrow \mathrm{Fe}^{2+}+\mathrm{AscH} \\
& \mathrm{Fe}^{2+}+\mathrm{H}_{2} \mathrm{O}_{2} \stackrel{\mathrm{k}_{2}=63 \mathrm{M}^{-1} \mathrm{~s}^{-1}}{\longrightarrow} \mathrm{Fe}^{3+}+\dot{\mathrm{OH}}+\mathrm{OH}^{-} \\
& \mathrm{Fe}^{3+}+\mathrm{H}_{2} \mathrm{O}_{2} \stackrel{\mathrm{K}=3.1^{*} 10^{-3}}{\rightleftarrows} \mathrm{Fe}^{3+}\left(\mathrm{HO}_{2}\right)^{2+}+\mathrm{H}^{+} \\
& \mathrm{Fe}^{3+}\left(\mathrm{HO}_{2}\right)^{2+} \stackrel{\mathrm{k}_{3}=2.7^{*} 10^{-3} \mathrm{~s}^{-1}}{\longrightarrow} \mathrm{Fe}^{2+}+\mathrm{HO}_{2}
\end{aligned}
$$

Scheme 3. Reduction of $\mathrm{Fe}^{3+}$ by ascorbic acid and the Fenton reaction [66].

Due to the importance of these processes for living systems, the characteristics of these reactions in various environments attract considerable attention [27-32,38-40]. Taking into account that at physiological conditions most of the iron is in bound forms, the main question is whether ascorbic acid is able to compete in iron binding with other chelators or transport proteins, following the $\mathrm{Fe}^{2+}$ formation. To answer this question, in the present study the behaviour of the FeL1 3 chelate complex in the presence of ascorbic acid has been studied by UV-Vis optical method at neutral $(\mathrm{pH}=7.4)$ and weak acidic $(\mathrm{pH}=4-5)$ media. FeL1 3 chelate complex has a broad absorption band of around $500 \mathrm{~nm}$ in water solution (Figure 2a). It was found that the addition of ascorbic acid at neutral $\mathrm{pH}=7.4$ results in shifting the position of this band to a lower wavelength (Figure $2 b$ ). We can assume that this change of absorption maximum is due to the substitution of one ligand L1 to ascorbate ion with the formation of a new mixed chelate complex FeL1 $1_{2}$ Asc. The rate of this process is concentration-dependent, with $\mathrm{k} \approx 6 \mathrm{M}^{-1} \mathrm{~s}^{1}$. It is important that this mixed chelate complex is redox stable at physiological $\mathrm{pH}(7.4)$, no reduction in intensity has been detected in this study. However, in a weak acid solution at $\mathrm{pH}=4.0$ this new complex was unstable, and decayed completely with a characteristic time of $350 \mathrm{~s}$ at $\left[\mathrm{AscH}^{-}\right]=0.05 \mathrm{mM}$, and $\sim 25 \mathrm{~s}$ at $\left[\mathrm{AscH}^{-}\right]=0.5 \mathrm{mM}$ (Figure 2c). We can assume that the reduction of iron in the mixed chelate complex occurs in its protonated form (Scheme 4), similar to that established by Keypour for the Fe(III)-Asc complex [47]. Additionally, the increase of the intensity of L1 proton peaks in the NMR spectrum (Figure 3) is an additional confirmation of the decomposition of the chelate complexes FeL1 ${ }_{2}$ Asc. The observed effect is due to the decrease of paramagnetic broadening of the L1 NMR signals. 


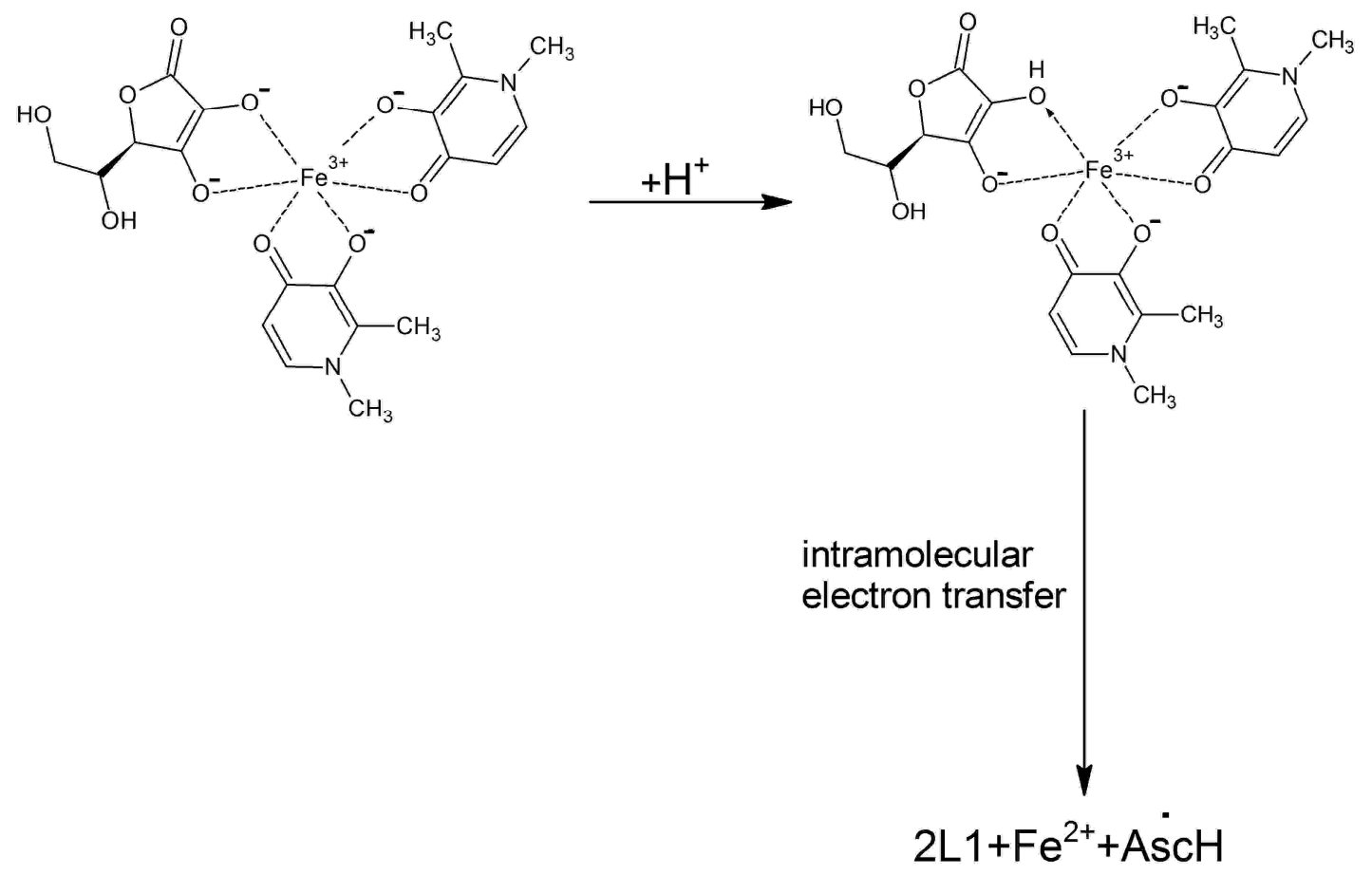

Scheme 4. Iron reduction in the mixed chelate complex FeL1 ${ }_{2}$ Asc.

The slow oxidation of ascorbic acid and formation of DHA in the reaction with the FeL1 $1_{3}$ chelate complex in weak acidic solution was confirmed by ${ }^{1} \mathrm{H}$ NMR spectroscopy. Figure 3 shows the appearance of the DHA signal after the addition of FeL1 3 complex to the ascorbic acid solution, with a further increase in the amount of product during the next hour. We assume that further decomposition of ascorbic acid occurs due to the release of ferrous ions from the L1 complex $[39,54]$ and its oxidation by dissolved oxygen [10]. It should be noted that there are only a few examples of experimentally detected mixed ligand iron complexes of ascorbic acid, but all of them are redox-active, presumably because the chelators involved are weaker than L1 [48-50].

The antioxidant/pro-oxidant activity of ascorbic acid was also observed in the present study in the Fenton reaction using the EPR spin trapping technique. The Fenton reactions i.e., the oxidation of organic substrates by $\mathrm{Fe}^{2+}$ and hydrogen peroxide has been known for more than a century, and its mechanism was reinvestigated by many others during the recent decades $[67,68]$.

Iron and in particular its ferrous form $\left(\mathrm{Fe}^{2+}\right)$ is the major catalyst of radical reactions in biological systems and the cause of damage in diseases related to oxidative stress. Although no free ferrous iron circulates in blood under normal conditions, the excess "focal" iron was detected in various organs in many diseases [69]. Nontransferrin-bound iron found in plasma is also well documented in iron overloaded diseases like thalassaemia, where transferrin is fully saturated with iron [28]. The presence of labile, nonprotein-bound iron is also considered a source of continuous toxicity, which has been implicated in the pathogenesis of many diseases including ageing, atherosclerosis, neurodegenerative, and kidney diseases, as well as cancer [26].

A number of EPR spin trapping studies have demonstrated the production of reactive oxygen radicals during the oxidation reaction of $\mathrm{Fe}^{2+}$ to $\mathrm{Fe}^{3+}$ ions with hydrogen peroxide (see Scheme 3) $[67,68,70]$. In this context, the method of spin trapping allows the transformation of extremely short-lived radicals to long-lived ones, and is successfully used in the study of biologically relevant free radicals, especially ROS, such as hydroxyl radical, peroxyl radical, and singlet oxygen [55-57,64,71]. It has been shown that the use of the TMIO spin trap (2,2,4-trimethyl-2H-imidazole-1-oxide) has certain advantages over the widely used DMPO (5,5-dimethylpyrroline-N-oxide) and PBN ( $\alpha$-phenyl N-t-butyl nitrone) spin traps in the trapping of several types of radicals and in the interpretation of molecular mechanisms involved in the reaction $[55,56,64]$. 
In the present, study the formation of $\bullet \mathrm{OH}$ radicals was proven by the detection of the corresponding TMIO-OH spin adduct with hfi (hyperfine interaction) constants: $a(N)=14.07 \mathrm{G}$, $\mathrm{a}(\mathrm{H})=16.08 \mathrm{G}$. It is important to note, that the signal from $\mathrm{OH}$ spin adduct increases in the presence of ascorbic acid in the reaction mixture in the absence of L1, as well as at low concentration of L1, as shown in Figure 4a,b. It can be suggested that ascorbic acid turns on the cyclic reaction of $\bullet \mathrm{OH}$ radical production (Scheme 5).

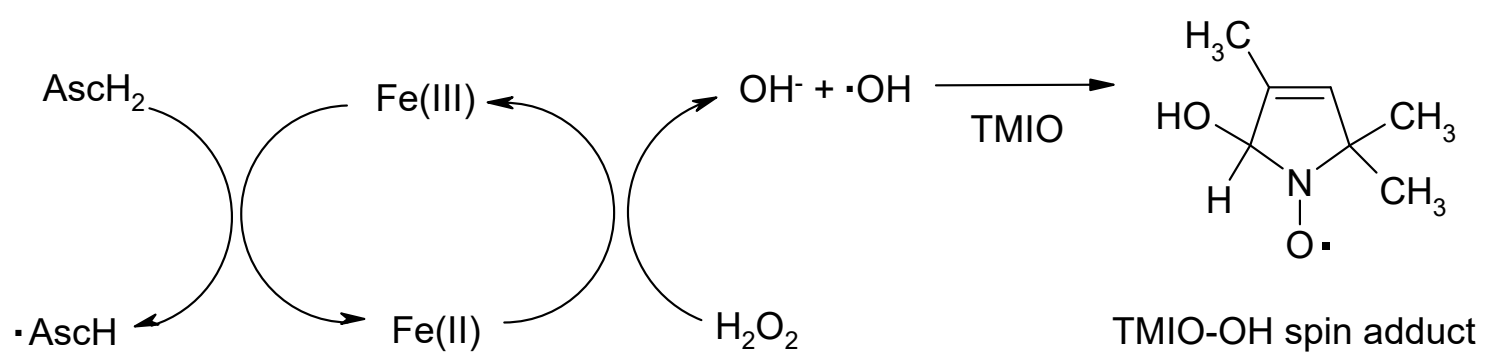

Scheme 5. The ascorbic acid enhanced Fenton reaction.

Similar effects of a significant increase in the yield of free radicals in cyclic redox reactions have recently been demonstrated in the system containing iron ions and anticancer quinone-chelators [72,73]. The authors also demonstrated the synergetic effect of iron and chelating compounds on cytotoxicity against a number of cancer cell lines. In this context, the pro-oxidant activity of ascorbic acid can be considered as an additional factor in cancer therapy in combination with other anticancer agents and especially with redox-active quinone-chelators [20,72-75]. Similar cyclic schemes of ROS formation have also been suggested earlier in a carotenoid driven Fenton reaction [62].

In contrast, the amount of TMIO-OH spin adduct decreases in the presence of ascorbic acid in the solution at concentration ratios of $\mathrm{L} 1: \mathrm{Fe}=2: 1$ and 4:1. So, in these conditions, the antioxidant effect of ascorbic acid has been detected. This experiment confirmed our conclusion drawn from the UV-Vis optical study on the formation of the mixed chelate complex FeL1 ${ }_{2} \mathrm{Asc}$. This complex is redox inactive in physiological conditions at $\mathrm{pH}=7.4$, and much less active than $\mathrm{Fe}(\mathrm{III})$-Asc complex in weak acidic media at $\mathrm{pH}=3-5$. It is known that the stoichiometry of the chelate complex $\mathrm{L} 1$ with $\mathrm{Fe}^{3+}$ ions is sensitive to $\mathrm{pH}$ value. In a slightly acidic medium $(\mathrm{pH}=3-5)$, the redox-active $\mathrm{FeL}_{2}{ }^{+}$complex is also present in solution in equilibrium with $\mathrm{FeL}_{3}$ complex [44]. This observation is in agreement with data published by Devanur with coauthors [63] who observed hydroxyl radical generation (detected using the deoxyribose oxidation assay) in Fenton reaction with participation of the redox-active $\mathrm{FeL} 1_{2}{ }^{+}$at low concentration of ascorbic acid.

It is envisaged that different mixed chelate complexes of iron with ascorbic acid and nutrients or drugs with chelating properties such as L1 will be formed in vivo in the gastrointestinal tract which may have implications on iron absorption [76-78]. Similarly, in the absence of chelators, the reduction of ferric iron to ferrous iron, which was shown in these studies, once again confirmed the advisability of using ascorbic acid to increase iron absorption, since ferrous iron is better absorbed than ferric iron [76-78].

It should be noted that ascorbic acid is also able to form a chelate complex with $\mathrm{Fe}^{2+}$ ions. The existence of the ferrous ascorbate chelate complex has been established in a number of studies $[79,80]$. However, this complex cannot be compared in efficiency with other chelating molecules responsible for iron transport, primarily DMT1 (divalent metal transporter 1) [81]. In addition to its well-established reduction of ferric iron to provide a bioavailable supply of ferrous iron to DMT1, ascorbic acid also enhances directly the uptake of ferric iron into Caco-2 cells through the formation of the $\mathrm{Fe}^{3+}$-ascorbate complex [82]. Since DMT1 is not involved in the uptake of this complex, further work is required to identify the transporter system (chelating agent) which inhibits $\mathrm{Fe}^{3+}$ reduction by ascorbate.

Considering the possible biological role of ferrous ascorbate complex, the main question is whether this complex is redox-active or not. Some recent studies have confirmed the redox activity of a mixture 
of ascorbic acid with $\mathrm{Fe}^{2+}$ in the Fenton reaction [83,84]. For example, oxidation of benzoic acid by the Fenton reaction occurs more effectively in the presence of ascorbic acid [85]. The initial reactivity of ferrous ascorbate with hydrogen peroxide is the same as that of free ferrous ions. However, when $\mathrm{Fe}^{2+}$ is oxidised to $\mathrm{Fe}^{3+}$, the reaction rate decreases by one order due to the slow reaction of $\mathrm{Fe}^{3+}$ with hydrogen peroxide (see Scheme 3). Furthermore, in the presence of ascorbic acid the starting reaction rate is kept high due to the fast transition of $\mathrm{Fe}^{3+}$ to $\mathrm{Fe}^{2+}$ [85].

It is worth considering several other biological implications of the interaction of ascorbic acid and iron, such as the prospect of an increase in ROS production and toxicity under conditions of iron loading, especially when using a combination of ascorbic acid and chelating agents. Furthermore, it should also be considered that molecular modification such as oxidation could result in the reduction or complete inactivation of the biological functions of ascorbic acid and its role as a major vitamin.

\section{Materials and Methods}

\subsection{Materials}

Ascorbic acid (99\%), $\mathrm{FeCl}_{3}(97 \%)$, and $\mathrm{H}_{2} \mathrm{O}_{2}$ (35.5\%) were obtained from Sigma-Aldrich, Moscow, Russia. L1 was received from LIPOMED Inc, Arlesheim, Switzerland. The spin trap TMIO (2,2,4-trimethyl-2H-imidazole-1-oxide, 98\%) used in EPR experiments was obtained from Fluka, Buchs, Switzerland. All compounds were used as received. All experiments were carried out at room temperature.

\subsection{Methods}

UV-Vis absorption spectra of all compounds and chelate complexes and the kinetic measurements were carried out using a Shimadzu UV-2401-PC spectrophotometer. The samples were prepared in distilled water, and all measurements were made in a $1 \mathrm{~cm}$ quartz cuvette. The $\mathrm{pH}$ of the solution was adjusted by the addition of $\mathrm{HCl}$ or $\mathrm{KOH}$ stock solution.

${ }^{1} \mathrm{H}$ NMR spectra were recorded on the Bruker Avance HD III NMR spectrometer $\left(500 \mathrm{MHz}{ }^{1} \mathrm{H}\right.$ operating frequency). The samples were prepared in $\mathrm{D}_{2} \mathrm{O}(99.9 \% \mathrm{D}$, Aldrich) at $\mathrm{pH}=4.1$.

The EPR spectra of spin adducts were recorded on a Bruker EMX EPR spectrometer. The EPR parameters: microwave bridge (frequency $10.112 \mathrm{GHz}$, power $20.65 \mathrm{~mW}$ ) and signal channel (receiver gain $2 \times 10^{5}$, modulation frequency $100 \mathrm{kHz}$, modulation amplitude $1.00 \mathrm{G}$ ). The Fenton reaction was carried out in distilled water (at $\mathrm{pH}=3.0-3.5$ ) with $20 \mathrm{mM} \mathrm{TMIO}, 3 \mathrm{mM} \mathrm{FeCl}_{3}$, and at various concentrations of $\mathrm{L} 1, \mathrm{H}_{2} \mathrm{O}_{2}$, and ascorbic acid. The reaction started with the addition of $\mathrm{FeCl}_{3}$ to the reaction mixture. No spin adducts were detected before the addition of $\mathrm{FeCl}_{3}$.

\section{Conclusions}

Ascorbic acid is known as a multifaceted compound, and its role in nature and especially in the human body is still the subject of many investigations and debates. On the one hand, ascorbic acid is one of the most important natural substances in the human diet. It performs biological functions as a reducing agent and coenzyme in certain metabolic processes and also serves as an antioxidant. On the other hand, ascorbic acid can act as a chelator of metal ions and also as a source of toxic free radicals in the iron and copper catalysed reactions. This is why the role of ascorbic acid in the iron and copper overload condition is widely discussed and requires further elucidation. Iron is the major catalyst of free radical reactions in biological systems and of free radical damage in the diseases related to oxidative stress. From the results presented in this study, we can conclude that ascorbic acid exhibits predominantly pro-oxidant activity in the presence of iron ions by reducing $\mathrm{Fe}^{3+}$ ion to $\mathrm{Fe}^{2+}$, thus triggering a cyclic Fenton type reaction, and producing additional amounts of hydroxyl radicals. It has previously been shown in many studies that the chelate complexes of ascorbic acid with ferric iron are redox-active and undergo intramolecular electron transfer with the formation of ascorbyl radicals and $\mathrm{Fe}^{2+}$ ions. We propose that the pro-oxidant activity of ascorbic acid in the iron overload condition should be taken into consideration when chelation therapy is applied. In contrast, 
in the case of cancer therapy, the pro-oxidant activity of ascorbic acid in the presence of iron can be utilised as an additional factor in the combination therapies with other anticancer agents, in particular with redox-active quinone-chelators.

The ability of ascorbic acid to reduce ferric iron to ferrous iron at acidic and neutral $\mathrm{pH}$ confirms the suitability of ascorbic acid to increase iron absorption. It was also first established that in the ternary chelate complex of iron, $\mathrm{L} 1$, and ascorbic acid ( $\mathrm{FeL} 1_{2} \mathrm{Asc}$ ), ascorbic acid is apparently not able to reduce ferric iron at physiological $\mathrm{pH}$. Therefore, we can assume that ascorbic acid can be used as an antioxidant in cases of L1 chelation therapy. Surprisingly, the formation of a mixed chelate complex occurs even at low concentrations of ascorbate, despite the significantly lower stability constants of the ascorbate complex with iron than the L1 complex. Further investigations are needed for determining the biological effects of ascorbic acid at the molecular level and in particular the effects of mixed iron complexes of iron with ascorbic acid and other chelators.

Author Contributions: Conceptualisation, V.A.T., N.E.P., and G.J.K.; formal analysis, V.A.T. and T.V.K.; funding acquisition, V.A.T. and N.E.P.; investigation, V.A.T. and T.V.K.; methodology, V.A.T., N.E.P., and T.V.K.; project administration, N.E.P.; resources, V.A.T.; supervision, N.E.P. and G.J.K.; validation, N.E.P. and G.J.K.; writing —original draft preparation, V.A.T. and N.E.P.; writing-review and editing, V.A.T., N.E.P., and G.J.K.; All authors have read and agreed to the published version of the manuscript.

Funding: This research was supported by grants from the Russian Foundation for Basic Research No. 18-34-00343. The reported research was also funded by the Russian Ministry of Science and Education (State assignments No. 0304-2017-0009).

Acknowledgments: We thank Christina N. Kontoghiorghe for reviewing and commenting on the manuscript.

Conflicts of Interest: The authors declare no conflict of interest.

\section{References}

1. Macan, A.M.; Kraljević, T.G.; Raić-malić, S. Therapeutic perspective of vitamin C and its derivatives. Antioxidants 2019, 8, 247. [CrossRef]

2. Naidu, K.A. Vitamin C in human health and disease is still a mystery? An overview. Nutr. J. $2003,2,7$. [CrossRef] [PubMed]

3. Pham-Huy, L.A.; He, H.; Pham-Huy, C. Free radicals, antioxidants in disease and health. Int. J. Biomed. Sci. 2008, 4, 89-96. [PubMed]

4. Young, I.S.; Woodside, J.V. Antioxidants in health and disease. J. Clin. Pathol. 2001, 54, 176-186. [CrossRef] [PubMed]

5. Rahman, K. Studies on free radicals, antioxidants, and co-factors. Clin. Interv. Aging 2007, 2, 219-236.

6. Kontoghiorghe, C.N.; Kolnagou, A.; Kontoghiorghes, G.J. Phytochelators intended for clinical use in iron overload, other diseases of iron imbalance and free radical pathology. Molecules 2015, 20, 20841-20872. [CrossRef]

7. Bielski, B.H.J.; Allen, A.O.; Schwarz, H.A. Mechanism of Disproportionation of Ascorbate Radicals. J. Am. Chem. Soc. 1981, 103, 3516-3518. [CrossRef]

8. Bielski, B.H.J. Chemistry of Ascorbic Acid Radicals. In Ascorbic Acid: Chemistry, Metabolism, and Uses; Seib, P.A., Tolbert, B.M., Eds.; American Chemical Society: Washington, WA, USA, 1982; pp. 81-100. ISBN 9780841206328.

9. Halliwell, B.; Gutteridge, J.M.C. The antioxidants of human extracellular fluids. Arch. Biochem. Biophys. 1990, 280, 1-8. [CrossRef]

10. Koppenol, W.H.; Hider, R.H. Iron and redox cycling. Do's and don'ts. Free Radic. Biol. Med. 2019, 133, 3-10. [CrossRef]

11. Erdem, G.; Öner, C.; Önal, A.M.; Kisakürek, D.; Ögüs, A.Y. Free radical mediated interaction of ascorbic acid and ascorbate/Cu(II) with viral and plasmid DNAs. J. Biosci. 1994, 19, 9-17. [CrossRef]

12. Gerster, H. High-dose vitamin C: A risk for persons with high iron stores? Int. J. Vitam. Nutr. Res. 1999, 69, 67-82. [CrossRef] [PubMed]

13. Carr, A.; Frei, B. Does vitamin C act as a pro-oxidant under physiological conditions? FASEB J. 1999, 13, 1007-1024. [CrossRef] [PubMed] 
14. Van Gorkom, G.N.Y.; Lookermans, E.L.; Van Elssen, C.H.M.J.; Bos, G.M.J. The effect of vitamin C (Ascorbic acid) in the treatment of patients with cancer: A systematic review. Nutrients 2019, 11, 977. [CrossRef] [PubMed]

15. Borst, P. Mega-dose vitamin C as therapy for human cancer? Proc. Natl. Acad. Sci. USA 2008, 105, 95. [CrossRef]

16. Frei, B.; Lawson, S. Vitamin C and cancer revisited. Proc. Natl. Acad. Sci. USA 2008, 105, 11037-11038. [CrossRef]

17. Chen, Q.; Espey, M.G.; Sun, A.Y.; Pooput, C.; Kirk, K.L.; Krishna, M.C.; Khosh, D.B.; Drisko, J.; Levine, M. Pharmacologic doses of ascorbate act as a prooxidant and decrease growth of aggressive tumor xenografts in mice. Proc. Natl. Acad. Sci. USA 2008, 105, 11105-11109. [CrossRef]

18. Rottenberg, S.; Jonkers, J. Modeling therapy resistance in genetically engineered mouse cancer models. Drug Resist. Updat. 2008, 11, 51-60. [CrossRef]

19. Verrax, J.; Cadrobbi, J.; Marques, C.; Taper, H.; Habraken, Y.; Piette, J.; Calderon, P.B. Ascorbate potentiates the cytotoxicity of menadione leading to an oxidative stress that kills cancer cells by a non-apoptotic caspase-3 independent form of cell death. Apoptosis 2004, 9, 223-233. [CrossRef]

20. Verrax, J.; Stockis, J.; Tison, A.; Taper, H.S.; Calderon, P.B. Oxidative stress by ascorbate/menadione association kills K562 human chronic myelogenous leukaemia cells and inhibits its tumour growth in nude mice. Biochem. Pharmacol. 2006, 72, 671-680. [CrossRef]

21. Cameron, E.; Pauling, L. Supplemental ascorbate in the supportive treatment of cancer: Reevaluation of prolongation of survival times in terminal human cancer. Proc. Natl. Acad. Sci. USA 1978, 75, 4538-4542. [CrossRef]

22. Wittes, R.E. Vitamin C and Cancer. N. Engl. J. Med. 1985, 312, 178-179. [CrossRef] [PubMed]

23. Hoffer, L.J.; Levine, M.; Assouline, S.; Melnychuk, D.; Padayatty, S.J.; Rosadiuk, K.; Rousseau, C.; Robitaille, L.; Miller, W.H. Phase I clinical trial of i.v. ascorbic acid in advanced malignancy. Ann. Oncol. 2008, 19, 1969-1974. [CrossRef] [PubMed]

24. Padayatty, S.J.; Riordan, H.D.; Hewitt, S.M.; Katz, A.; Hoffer, L.J.; Levine, M. Intravenously administered vitamin C as cancer therapy: Three cases. Can. Med. Assoc. J. 2006, 174, 937-942. [CrossRef]

25. Assouline, S.; Miller, W.H. High-dose vitamin C therapy: Renewed hope or false promise? Can. Med. Assoc. J. 2006, 174, 956-957. [CrossRef] [PubMed]

26. Kontoghiorghes, G.J.; Kontoghiorghe, C.N. Prospects for the introduction of targeted antioxidant drugs for the prevention and treatment of diseases related to free radical pathology. Expert Opin. Investig. Drugs 2019, 28, 593-603. [CrossRef] [PubMed]

27. Kalinowski, D.S.; Stefani, C.; Toyokuni, S.; Ganz, T.; Anderson, G.J.; Subramaniam, N.V.; Trinder, D.; Olynyk, J.K.; Chua, A.; Jansson, P.J.; et al. Redox cycling metals: Pedaling their roles in metabolism and their use in the development of novel therapeutics. Biochim. Biophys. Acta-Mol. Cell Res. 2016, 1863, 727-748. [CrossRef] [PubMed]

28. Breuer, W.; Hershko, C.; Cabantchik, Z.I. The importance of non-transferrin bound iron in disorders of iron metabolism. Transfus. Sci. 2000, 23, 185-192. [CrossRef]

29. Hahn, P.; Milam, A.H.; Dunaief, J.L. Maculas affected by age-related macular degeneration contain increased chelatable iron in the retinal pigment epithelium and Bruch's membrane. Arch. Ophthalmol. 2003, 121, 1099-1105. [CrossRef]

30. Smith, M.A.; Harris, P.L.R.; Sayre, L.M.; Perry, G. Iron accumulation in Alzheimer disease is a source of redox-generated free radicals. Proc. Natl. Acad. Sci. USA 1997, 94, 9866-9868. [CrossRef]

31. Lv, Z.; Jiang, H.; Xu, H.; Song, N.; Xie, J. Increased iron levels correlate with the selective nigral dopaminergic neuron degeneration in Parkinson's disease. J. Neural Transm. 2011, 118, 361-369. [CrossRef]

32. Richardson, D.R. Iron chelators as therapeutic agents for the treatment of cancer. Crit. Rev. Oncol. Hematol. 2002, 42, 267-281. [CrossRef]

33. Nuñez, M.T.; Chana-Cuevas, P. New perspectives in iron chelation therapy for the treatment of neurodegenerative diseases. Pharmaceuticals 2018, 11, 109. [CrossRef] [PubMed]

34. Tosato, M.; Di Marco, V. Metal chelation therapy and Parkinson's disease: A critical review on the thermodynamics of complex formation between relevant metal ions and promising or established drugs. Biomolecules 2019, 9, 269. [CrossRef] [PubMed] 
35. Kalinowski, D.S.; Richardson, D.R. Future of toxicology-Iron chelators and differing modes of action and toxicity: The changing face of iron chelation therapy. Chem. Res. Toxicol. 2007, 20, 715-720. [CrossRef] [PubMed]

36. Heffeter, P.; Pape, V.F.S.; Enyedy, É.A.; Keppler, B.K.; Szakacs, G.; Kowol, C.R. Anticancer thiosemicarbazones: Chemical properties, interaction with iron metabolism, and resistance development. Antioxid. Redox Signal. 2019, 30, 1062-1082. [CrossRef] [PubMed]

37. Kuźnik, N.; Chmielniak, U. Studies on the redox activity of iron N,O-complexes: Potential T1-contrast agents. Redox Rep. 2016, 21, 37-44. [CrossRef]

38. Tyagi, N.; Chakraborty, A.; Singh, U.P.; Roy, P.; Ghosh, K. Mononuclear iron(III) complexes of tridentate ligands with efficient nuclease activity and studies of their cytotoxicity. Org. Biomol. Chem. 2015, 13, 11445-11458. [CrossRef]

39. Timoshnikov, V.A.; Kobzeva, T.V.; Polyakov, N.E.; Kontoghiorghes, G.J. Inhibition of Fe2+- and Fe3+- induced hydroxyl radical production by the iron-chelating drug deferiprone. Free Radic. Biol. Med. 2015, 78, 118-122. [CrossRef]

40. Timoshnikov, V.A.; Kobzeva, T.; Selyutina, O.Y.; Polyakov, N.E.; Kontoghiorghes, G.J. Effective inhibition of copper-catalyzed production of hydroxyl radicals by deferiprone. J. Biol. Inorg. Chem. 2019, 24, 331-341. [CrossRef]

41. Kontoghiorghes, G.; Eracleous, E.; Economides, C.; Kolnagou, A. Advances in Iron Overload Therapies. Prospects for Effective Use of Deferiprone (L1), Deferoxamine, the New Experimental Chelators ICL670, GT56-252, L1NAll and their Combinations. Curr. Med. Chem. 2005, 12, 2663-2681. [CrossRef]

42. Kontoghiorghes, G.J. Clinical use, therapeutic aspects and future potential of deferiprone in thalassemia and other conditions of iron and other metal toxicity. Drugs Today 2001, 37, 23-35. [CrossRef] [PubMed]

43. Kontoghiorghes, G.J. Prospects for introducing deferiprone as potent pharmaceutical antioxidant. Front. Biosci. Elite Ed. 2009, 1, 161-178.

44. Nurchi, V.M.; Crisponi, G.; Pivetta, T.; Donatoni, M.; Remelli, M. Potentiometric, spectrophotometric and calorimetric study on iron(III) and copper(II) complexes with 1,2-dimethyl-3-hydroxy-4-pyridinone. J. Inorg. Biochem. 2008, 102, 684-692. [CrossRef] [PubMed]

45. Motekaitis, R.J.; Martell, A.E. Stabilities of the iron(III) chelates of 1,2-dimethyl-3-hydroxy-4-pyridinone and related ligands. Inorganica Chim. Acta 1991, 183, 71-80. [CrossRef]

46. Charalambous, J.; Dodd, A.; McPartin, M.; Watondo, S.O.C.; Pathirana, N.D.; Powell, H.R. Synthesis and X-ray crystal structures of tris (1,2-dimethyl-3-hydroxypyrid-onato)iron (III). Polyhedron 1988, 7, 2235-2237. [CrossRef]

47. Keypour, H.; Silver, J.; Wilson, M.T.; Hamed, M.Y. Studies on the reactions of ferric iron with ascorbic acid. A study of solution chemistry using Mössbauer spectroscopy and stopped-flow techniques. Inorganica Chim. Acta 1986, 125, 97-106. [CrossRef]

48. Grillet, L.; Ouerdane, L.; Flis, P.; Hoang, M.T.T.; Isaure, M.P.; Lobinski, R.; Curie, C.; Mari, S. Ascorbate efflux as a new strategy for iron reduction and transport in plants. J. Biol. Chem. 2014, 289, 2515-2525. [CrossRef]

49. Nayak, S.; Dash, A.C. Phenol-amide chelates of iron(III). Kinetics and mechanism of reversible formation of (diaqua) (1,3) bis (2-hydroxybenzamido)propaneiron(III) and its reactions with thiocyanate, azide, imidazole, sulphur(IV) and ascorbic acid in aqueous medium. Indian J. Chem.-Sect. A Inorganic Phys. Theor. Anal. Chem. 2003, 42, 2427-2438.

50. Rath, H.; Pradhan, G.C.; Dash, A.C. Phenol-amide chelate of iron(III): Its redox activity with L-ascorbic acid. Indian J. Chem.-Sect. A Inorganic Phys. Theor. Anal. Chem. 2001, 40, 437-441.

51. Ortega-Castro, J.; Frau, J.; Casasnovas, R.; Fernández, D.; Donoso, J.; Muñoz, F. High- and low-spin Fe(III) complexes of various AGE inhibitors. J. Phys. Chem. A 2012, 116, 2961-2971. [CrossRef]

52. Hininger, I.; Waters, R.; Osman, M.; Garrel, C.; Fernholz, K.; Roussel, A.M.; Anderson, R.A. Acute prooxidant effects of vitamin $\mathrm{C}$ in EDTA chelation therapy and long-term antioxidant benefits of therapy. Free Radic. Biol. Med. 2005, 38, 1565-1570. [CrossRef] [PubMed]

53. Zümreoglu-Karan, B. The coordination chemistry of Vitamin C: An overview. Coord. Chem. Rev. 2006, 250, 2295-2307. [CrossRef]

54. Merkofer, M.; Domazou, A.; Nauser, T.; Koppenol, W.H. Dissociation of CP20 from iron(II)(cp20)3: A pulse radiolysis study. Eur. J. Inorg. Chem. 2006, 2006, 671-675. [CrossRef] 
55. Dikalov, S.; Kirilyuk, I.; Grigor'ev, I. Spin trapping of O-, C-, and S-centered radicals and peroxynitrite by 2H-imidazole-1-oxides. Biochem. Biophys. Res. Commun. 1996, 218, 616-622. [CrossRef] [PubMed]

56. Haseloff, R.F.; Kirilyuk, I.A.; Dikalov, S.I.; Khramtsov, V.V.; Utepbergenov, D.I.; Blasig, I.E.; Grigor'ev, I.A. Synthesis and spin trapping applications of 2,2-dimethyl-d6-4-methyl-2H-imidazole-1-oxide-1-15N. Free Radic. Res. 1997, 26, 159-168. [CrossRef]

57. Fufezan, C.; Rutherford, A.W.; Krieger-Liszkay, A. Singlet oxygen production in herbicide-treated photosystem II. FEBS Lett. 2002, 532, 407-410. [CrossRef]

58. Buettner, G.R.; Manson, R.P. Spin-Trapping Methods for Detecting Superoxide and Hydroxyl Free Radicals In Vitro and In Vivo. In Critical Reviews of Oxidative Stress and Aging: Advances in Basic Science, Diagnostics and Intervention. Volumen I; Cutler, R.G., Rodriguez, H., Eds.; WORLD SCIENTIFIC: Singapore, 2003; pp. 27-38.

59. Vallelian, F.; Garcia-Rubio, I.; Puglia, M.; Kahraman, A.; Deuel, J.W.; Engelsberger, W.R.; Mason, R.P.; Buehler, P.W.; Schaer, D.J. Spin trapping combined with quantitative mass spectrometry defines free radical redistribution within the oxidized hemoglobin: Haptoglobin complex. Free Radic. Biol. Med. 2015, 85, 259-268. [CrossRef]

60. Polyakov, N.E.; Kruppa, A.I.; Leshina, T.V.; Konovalova, T.A.; Kispert, L.D. Carotenoids as antioxidants: Spin trapping EPR and optical study. Free Radic. Biol. Med. 2001, 31, 43-52. [CrossRef]

61. Polyakov, N.E.; Leshina, T.V.; Konovalova, T.A.; Hand, E.O.; Kispert, L.D. Inclusion complexes of carotenoids with cyclodextrins: 1HNMR, EPR, and optical studies. Free Radic. Biol. Med. 2004, 36, 872-880. [CrossRef]

62. Polyakov, N.E.; Leshina, T.V.; Konovalova, T.A.; Kispert, L.D. Carotenoids as scavengers of free radicals in a Fenton reaction: Antioxidants or pro-oxidants? Free Radic. Biol. Med. 2001, 31, 398-404. [CrossRef]

63. Polyakov, N.E.; Leshina, T.V.; Salakhutdinov, N.F.; Konovalova, T.A.; Kispert, L.D. Antioxidant and redox properties of supramolecular complexes of carotenoids with $\beta$-glycyrrhizic acid. Free Radic. Biol. Med. 2006, 40, 1804-1809. [CrossRef] [PubMed]

64. Krainev, A.G.; Williams, T.D.; Bigelow, D.J. Oxygen-centered spin adducts of 5,5-dimethyl-1-pyrroline N-oxide (DMPO) and 2H-imidazole 1-oxides. J. Magn. Reson. B 1996, 111, 272-280. [CrossRef]

65. Vásquez-Vivar, J.; Santos, A.M.; Junqueira, V.B.C.; Augusto, O. Peroxynitrite-mediated formation of free radicals in human plasma: EPR detection of ascorbyl, albumin-thiyl and uric acid-derived free radicals. Biochem. J. 1996, 314, 869-876. [CrossRef]

66. De Laat, J.; Gallard, H. Catalytic decomposition of hydrogen peroxide by Fe (III) in homogeneous aqueous solution: Mechanism and kinetic modeling. Environ. Sci. Technol. 1999, 33, 2726-2732. [CrossRef]

67. Perez-Benito, J.F. Iron(III)-hydrogen peroxide reaction: Kinetic evidence of a hydroxyl-mediated chain mechanism. J. Phys. Chem. A 2004, 108, 4853-4858. [CrossRef]

68. Barbusiński, K. Fenton reaction-Controversy concerning the chemistry. Ecol. Chem. Eng. S 2009, 16, 347-358.

69. Kontoghiorghe, C.N.; Kontoghiorghes, G.J. Antioxidant targeting by deferiprone in diseases related to oxidative damage. Front. Biosci. 2014, 19, 862. [CrossRef]

70. Polyakov, N.E.; Magyar, A.; Kispert, L.D. Photochemical and optical properties of water-soluble xanthophyll antioxidants: Aggregation vs complexation. J. Phys. Chem. B 2013, 117, 10173-10182. [CrossRef]

71. Karogodina, T.Y.; Sergeeva, S.V.; Stass, D.V. Stability and reactivity of free radicals: A physicochemical perspective with biological implications. Hemoglobin 2011, 35, 262-275. [CrossRef]

72. Polyakov, N.; Leshina, T.; Fedenok, L.; Slepneva, I.; Kirilyuk, I.; Furso, J.; Olchawa, M.; Sarna, T.; Elas, M.; Bilkis, I.; et al. Redox-Active Quinone Chelators: Properties, Mechanisms of Action, Cell Delivery, and Cell Toxicity. Antioxid. Redox Signal. 2018, 28, 1394-1403. [CrossRef]

73. Jabłońska-Trypuć, A.; Świderski, G.; Krętowski, R.; Lewandowski, W. Newly synthesized doxorubicin complexes with selected metals-Synthesis, structure and anti-breast cancer activity. Molecules 2017, 22, 1106. [CrossRef] [PubMed]

74. Silveira-Dorta, G.; Monzón, D.M.; Crisóstomo, F.P.; Martín, T.; Martín, V.S.; Carrillo, R. Oxidation with air by ascorbate-driven quinone redox cycling. Chem. Commun. 2015, 51, 7027-7030. [CrossRef] [PubMed]

75. Verrax, J.; Beck, R.; Dejeans, N.; Glorieux, C.; Sid, B.; Pedrosa, R.C.; Benites, J.; Vasquez, D.; Valderrama, J.A.; Buc Calderon, P. Redox-Active Quinones and Ascorbate: An Innovative Cancer Therapy That Exploits the Vulnerability of Cancer Cells to Oxidative Stress. Anticancer. Agents Med. Chem. 2011, 11, 213-221. [CrossRef] [PubMed] 
76. Kontoghiorghes, G.J.; Spyrou, A.; Kolnagou, A. Iron chelation therapy in hereditary hemochromatosis and thalassemia intermedia: Regulatory and non regulatory mechanisms of increased iron absorption. Hemoglobin 2010, 34, 251-264. [CrossRef] [PubMed]

77. Kontoghiorghes, G.; Kolnagou, A. Molecular Factors and Mechanisms Affecting Iron and Other Metal Excretion or Absorption in Health and Disease. The Role of Natural and Synthetic Chelators. Curr. Med. Chem. 2005, 12, 2695-2709. [CrossRef]

78. Kontoghiorghes, G.J. Chelators affecting iron absorption in mice. Arzneimittel-Forschung/Drug Res. 1990, 40, 1332-1335.

79. Muneta, P.; Kaisaki, F. Ascorbic acid-ferrous iron (Fe++)complexes and after cooking darkening of potatoes. Am. Potato J. 1985, 62, 531-536. [CrossRef]

80. Scheers, N.; Andlid, T.; Alminger, M.; Sandberg, A.S. Determination of fe $2+$ and fe + in aqueous solutions containing food chelators by differential pulse anodic stripping voltammetry. Electroanalysis 2010, 22, 1090-1096. [CrossRef]

81. Lane, D.J.R.; Robinson, S.R.; Czerwinska, H.; Bishop, G.M.; Lawen, A. Two routes of iron accumulation in astrocytes: Ascorbate-dependent ferrous iron uptake via the divalent metal transporter (DMT1) plus an independent route for ferric iron. Biochem. J. 2010, 432, 123-132. [CrossRef] [PubMed]

82. Thumser, A.E.; Rashed, A.A.; Sharp, P.A.; Lodge, J.K. Ascorbate enhances iron uptake into intestinal cells through formation of a FeCl3-ascorbate complex. Food Chem. 2010, 123, 281-285. [CrossRef]

83. Hou, X.; Huang, X.; Ai, Z.; Zhao, J.; Zhang, L. Ascorbic acid/Fe@Fe $\mathrm{O}_{3}$ : A highly efficient combined Fenton reagent to remove organic contaminants. J. Hazard. Mater. 2016, 310, 170-178. [CrossRef] [PubMed]

84. Kontoghiorghes, G.J.; Jackson, M.J.; Lunec, J. In vitro screening of iron chelators using models of free radical damage. Free Radic. Res. Commun. 1986, 2, 115-124. [CrossRef] [PubMed]

85. He, D.Q.; Zhang, Y.J.; Pei, D.N.; Huang, G.X.; Liu, C.; Li, J.; Yu, H.Q. Degradation of benzoic acid in an advanced oxidation process: The effects of reducing agents. J. Hazard. Mater. 2020, 382, 121090. [CrossRef] [PubMed]

(C) 2020 by the authors. Licensee MDPI, Basel, Switzerland. This article is an open access article distributed under the terms and conditions of the Creative Commons Attribution (CC BY) license (http://creativecommons.org/licenses/by/4.0/). 